\title{
津波移動床モデルの再現性に及ぼす 流砂パラメータの影響
}

\author{
有光 剛 1 - 松田 周吾 2 -村上 嘉謙 $3 \cdot$ 志方 建仁 4 -川崎 浩司 5 • \\ 三島 豊秋 5 - 清水 涼太郎 6 - 菅原 大助7 \\ 1正会員 関西電力株式会社 技術研究所（广661-0974 兵庫県尼崎市若王寺3-11-20） \\ E-mail:arimitsu.tsuyoshi@d3.kepco.co.jp \\ 2関西電力株式会社土木建築室＼cjkstart技術グループ（†530-8270 大阪市北区中之島3-6-16） \\ 3 関西電力株式会社 土木建築室 土木建築エンジニアリングセンター \\ ( (553-0003 大阪市福島区福島5-1-7 住友不動産西梅田ビル4F) \\ 4株式会社ニュージェック＼cjkstart港湾・海岸グループ（テ530-8270 大阪市北区本庄東2-3-20） \\ 5正会員 株式会社ハイドロソフト技術研究所（干 530-6126 大阪市北区中之島3-3-23 中之島ダイビル26F） \\ 6株式会社ハイドロソフト技術研究所（干530-6126 大阪市北区中之島3-3-23 中之島ダイビル26F） \\ 7 ふじのくに地球環境史ミュージアム（†422-8017 静岡市駿河区大谷5762）
}

\begin{abstract}
本研究では，津波移動床モデルにおける飽和浮遊砂濃度および流砂量係数の設定が地形変化の再現性に及 ぼす影響を把握するために, 東北地方太平洋沖地震津波による岩手県高田海岸における地形変化の再現計 算を行った. その結果, 得られる砂移動量の計算值が飽和浮遊砂濃度の設定方法によって大きく異なるこ とが明らかとなった。飽和浮遊砂濃度を固定值として与えると，十分な巻き上げが許容されないために地 形変化の再現性が不十分となった。一方で, 飽和浮遊砂濃度を流況に応じて可変とした場合は, 水理条件 による時空間的な砂移動量の変動を考慮することができ, 大規模な地形変化に対しても良好な再現性を得 ることができた。この際, 飽和浮遊砂濃度による制約の効果が大きいために, 流砂量係数による計算結果 の差異が小さいことが明らかとなった。
\end{abstract}

Key Words : movable bed model for tsunamis, saturation concentration of suspended sediment, sediment transport coefficients, topography change

\section{1. はじめに}

津波の作用により大量の土砂が巻き上げられて輸送さ れると，航路の埋没，陸域への堆積，海岸の侵食，発電 所取水設備の閉塞などの被害の原因となり得る。これら の被害の想定と，対策の検討を目的として，津波に伴う 砂移動・海底地形変化に関寸る研究が行われている.

津波に伴う砂移動評価に関しては，高橋ら）（以下， 高橋ら（1999））によって掃流砂層と浮遊砂層の交換砂 量を考慮したモデルが提案され，既に実務に用いられて (る2). しかしながら，津波による土砂移動に関する知 見は十分でなく, 現在も評価手法の高度化の取り組みが 継続されている，例えば，高橋ら ${ }^{3}$ ）（以下，高橋ら

（2011））は，大型水理実験により流砂量係数の粒径依 存性を確認し，粒径ごとの係数の值を提案している．ま た，森下・高橋》は，土砂移動に支配的な因子に着目し， 感度分析により土砂移動への応答特性を確認している.
一方で，砂移動計算時に設定する飽和浮遊砂濃度が再 現性に与える影響は大きく，その設定方法も課題となっ ている。浅井ら $)^{2}$ は, 安政東海沖地震津波による伊豆半 島における地形変化の計算を行い，飽和浮遊砂濃度の差 異が計算結果に大きな影響を及ぼすことを示している. 藤田らけ，1960年チリ津波による八戸港における地形 変化の再現計算の中で, 飽和浮遊砂濃度を変化させたパ ラメータスタディを実施している．その結果，飽和浮遊 砂濃度を $5 \%$ とした場合は堆積を過大評価するのに対し て，1〜2\%とすると良好な再現性が得られている．これ に対して，菅原ら》は，流況に応じて值を変化させるた めの飽和浮遊砂濃度算定式を提案している. 今井ら ${ }^{8}$, 山下らりは，それぞれ，北上川河口部，陸前高田市を対 象に, 東北地方太平洋沖地震津波による地形変化の再現 計算に菅原らの方法を適用し，妥当性を検証している.

このように，流砂量係数や飽和浮遊砂濃度などの流砂 パラメータの新たな設定方法が提案され，現地適用性の 


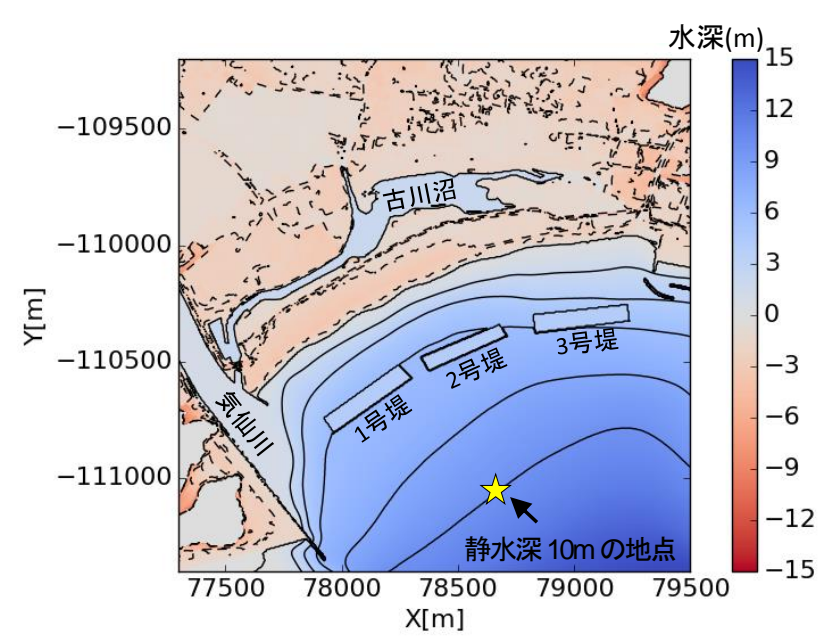

図-1 検討対象（高田海岸）の初期地形

検証が進んでいるものの，手法間の比較が示された例は なく，新たなパラメータの導入の効果が明確に把握され ていないのが現状である.

そこで，本検討では，流砂パラメータが砂移動・地形 変化計算の再現性に及ぼす影響の把握を目的として，異 なる流砂量係数および飽和浮遊砂濃度を用いて, 山下ら 9) と同様の東日本大震災時の岩手県陸前高田市の高田海 岸における地形変化の再現計算を行った.

\section{2. 津波移動床モデルによる計算方法}

\section{(1) 検討の概要}

山下らりは，流砂パラメータとして高橋ら（2011）の 流砂量係数，菅原ら》の飽和浮遊砂濃度設定方法を用い て, 高田海岸における東北地方太平洋沖地震津波による 地形変化の再現計算を行っている. 計算結果は, 現地調 査結果 ${ }^{10}$ との比較に基づき，遡上過程・浸水高などの津 波挙動や, 地形変化量・海域における堆積土砂の分布傾 向などの砂移動特性の良好な再現性が確認されている.

本検討では，山下ら9)を参考に計算条件を設定し，流 砂パラメータを変えた計算を行った。計算領域は波源域 を含む東日本の広範囲とし，津波波源にはSatakeら ${ }^{11} の$ モデルを使用した．ネスティングにより格子間隔を1215 $\mathrm{m}$ から $5 \mathrm{~m}$ まで徐々に細分化して，6階層の空間解像度で 計算を行った．紙面の制約により省略するが，津波水位 時系列を山下ら 9 ) と比較することで，伝播計算の妥当性 を確認している．高田海岸付近の計算初期地形を図-1に 示寸. 計算結果を現地調查結果 ${ }^{10)}$ （図-2）と比較し，流 砂パラメータによる再現性の差異を検討した。 なお，本 論文では, 地形変化量の正值を堆積, 負值を侵食と寸る.

\section{（2）砂移動・地形変化の計算方法}

津波による砂移動・地形変化の計算には，高橋ら （1999）による掃流砂層と浮遊砂層間の交換砂量を考慮

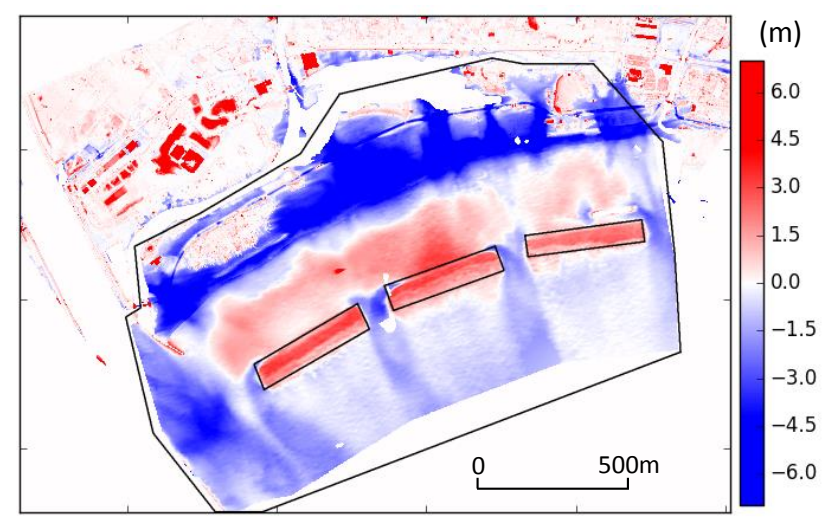

図-2 津波作用前後の地形変化の現地調査結果

表-1 計算条件（流砂パラメータ）

\begin{tabular}{c|c|c|c}
\multicolumn{3}{|c|}{ 表-1 計算条件（流砂パラメータ） } \\
\hline & \multicolumn{2}{|c|}{ 流砂量係数 } & \multirow{2}{*}{ 飽和浮遊砂濃度 } \\
\cline { 2 - 3 } & 巻き上け砂量 & 掃流砂量 & \\
\hline Case 1 & 0.012 & 21.0 & 固定 \\
\hline Case 2 & $4.4 \times 10^{-5}$ & 4.0 & $(1 \%)$ \\
\hline Case 3 & 0.012 & 21.0 & 可変 \\
\hline Case 4 & $4.4 \times 10^{-5}$ & 4.0 & (菅原ら円) \\
\hline
\end{tabular}

した津波移動床モデルを用いた．各ケースの流砂パラメ 一タの值を表-1に示す. 流砂量係数については, Case 1 およびCase 3では高橋ら（1999）の值とし，Case 2および Case 4では高橋ら（2011）の值を用いた．土砂の粒径は Naruseら ${ }^{12)}$ を参考に $0.267 \mathrm{~mm}$ とした。飽和浮遊砂濃度は, 1\%で固定とした場合（Case 1，2）と，菅原らかの式(1)を 用いて流況に応じて時空間的に值を変化させた場合

(Case 3，4）の計算を行った.

$$
C_{S}=\frac{\rho_{S} \rho_{W}}{\rho_{S}-\rho_{W}}\left(\frac{h^{4 / 3} w_{S}}{e_{S} n^{2} U^{3}}-1\right)^{-1}
$$

ここで，CSは飽和浮遊砂濃度 $\left(\mathrm{kg} / \mathrm{m}^{3}\right) ， \rho s$ は土砂の密 度 $\left(\mathrm{kg} / \mathrm{m}^{3}\right) ， \rho W$ は水の密度 $\left(\mathrm{kg} / \mathrm{m}^{3}\right), h$ は水深 $(\mathrm{m})$, $w s$ は土砂の沈降速度 $(\mathrm{m} / \mathrm{s}) ， e s$ は土砂の巻き上げ効率, $n$ はマニングの粗度係数 $\left(\mathrm{m}^{-1 / 3} \cdot \mathrm{s}\right), U$ は断面平均流速 $(\mathrm{m} / \mathrm{s})$ である．巻き上げ砂量を計算する際に，式(1)の 飽和浮遊砂濃度を上回らないように調整する。ただし， 移流や流況の急変などの巻き上げ以外の理由による超過 （過飽和）は許容する. なお，次章以降の浮遊砂濃度の 計算結果は，体積濃度で表示寸る.

砂移動計算においては土地利用区分別に土砂供給源を 限定し，砂は砂質地盤からの夕供給されることとし，シ ルト等で構成される泥の挙動は考慮していない.このた め，計算では，家屋や舗装面，田畑等における地盤高は， 地震による地盤低下量より低下しない，なお，堤防の破 堤を考慮するために，津波で被災した堤防の一部または 全てを砂質土で構成されるものとすることで，砂移動の 対象とした。 なお，津波伝播計算に用いる粗度係数は， 小谷ら ${ }^{13)}$ 参考に，土地利用別に設定した。 


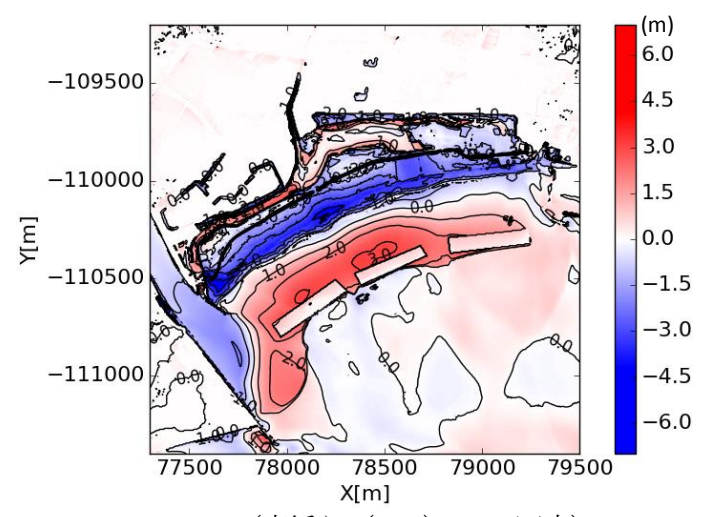

(a) Case1（高橋ら (1999)，1\%固定）

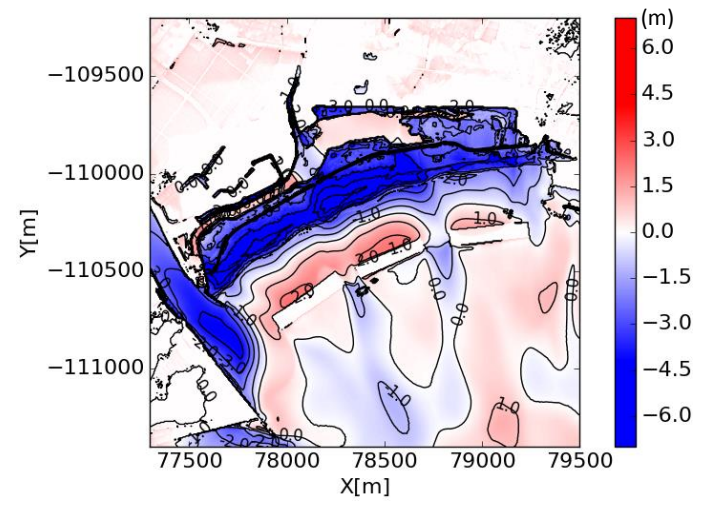

(c) Case3（高橋ら (1999），可変)

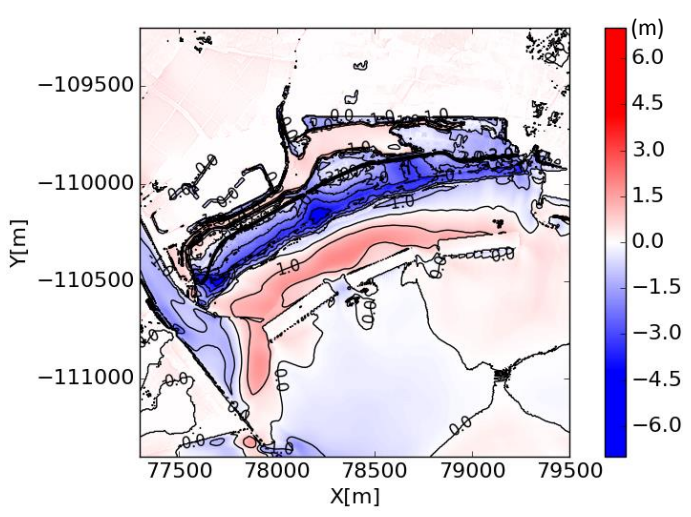

(b) Case2 (高橋ら (2011)，1\%固定)

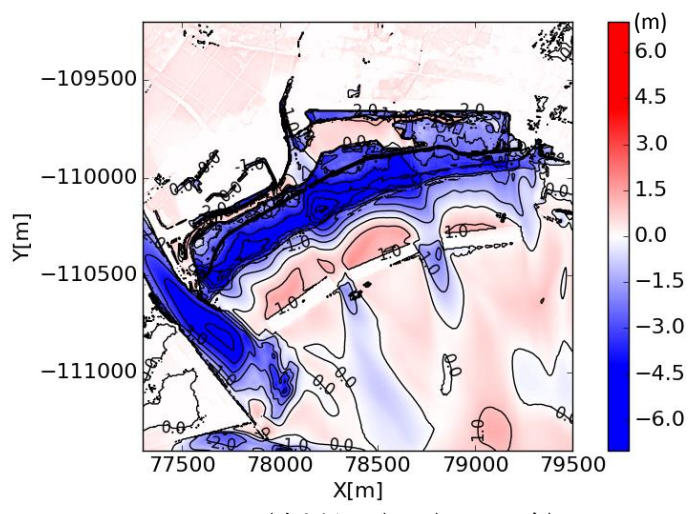

(d) Case4（高橋ら（2011），可変）

図-3 津波作用前後の地形変化の計算結果

\section{3. 津波作用前後の地形変化の計算結果}

\section{(1) 地形変化の計算結果}

図-3に, 津波作用前後の地形変化の計算結果を示寸. いずれの条件でも，高田松原および気仙川河口部の侵食 および人工リーフ岸側の堆積が計算されており，侵食域 と堆積域の分布は現地調査結果（図-2）を定性的に再現 できている. ただし，堆積厚や侵食深などの地形変化量 には条件による差異が認められ，例えば，Case 1 の人工 リーフ岸側の堆積厚は現地データや他のケースより大き い.また, Case 1，2では，気仙川河口付近の侵食深は小 さく, 人工リーフの2号堤と 3 号堤の間の侵食が認められ ないなど，現地調査結果との差異がみられる.

\section{（2）侵食・堆積土量}

図-2の黒実線で示した範囲内の堆積量および侵食量と, それらを差し引きした総変化量を図-4に示す，いずれの 条件でも総変化量は現地と同様に侵食傾向を示している ものの, ケースによる地形変化量の差異が認められる.

Case 1，2では流砂量係数による差異はあるものの，両ケ 一スとも現地データと比較すると堆積量が大きいのに対 して侵食量は小さく計算されており, 総変化量では侵食 量が過小評価となっている，一方，Case 3，40流砂量係 数による違いは小さく, 両ケースの堆積量・侵食量は現 地を良好に再現できている.

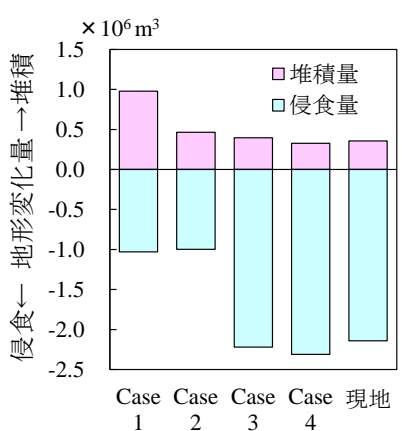

(a)侵食量・堆積量

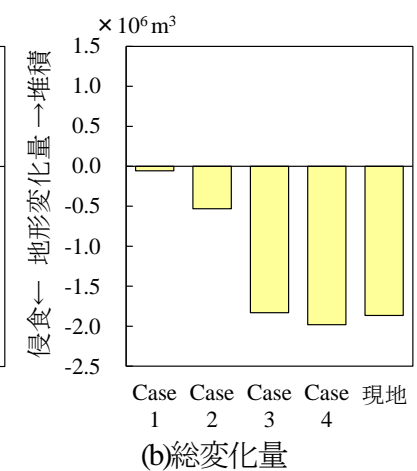

図-4 地形変化量の計算結果と現地データの比較

\section{4. 流砂パラメータが地形変化の再現性に及ぼす 影響}

\section{(1) 津波挙動とシールズ数}

図-5に，静水深 $10 \mathrm{~m}$ の地点（図-1中の星印）における 水位・流速・シールズ数の計算結果の時系列を示す.こ こで，流速は2方向の成分を合成した絶対值とし，シー ルズ数は流速絶対值を用いて計算した值である．同じ波 源を用いているため，条件による津波挙動の差異は小さ い. ただし，条件によって地形の計算結果が異なるため に，計算時間の後半にはケース間の差異が現れる.

この地点の水位（図-5(a)）は，地震発生の約30分後か ら1波目による上昇が始まり，約45分後に押し波のピー 


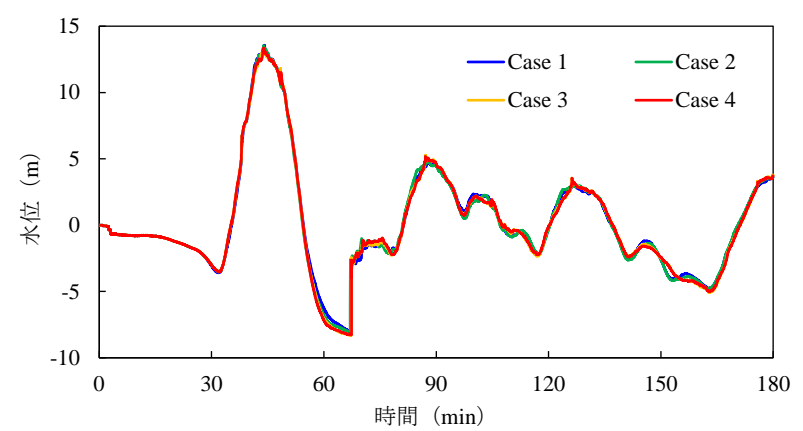

(a) 水位

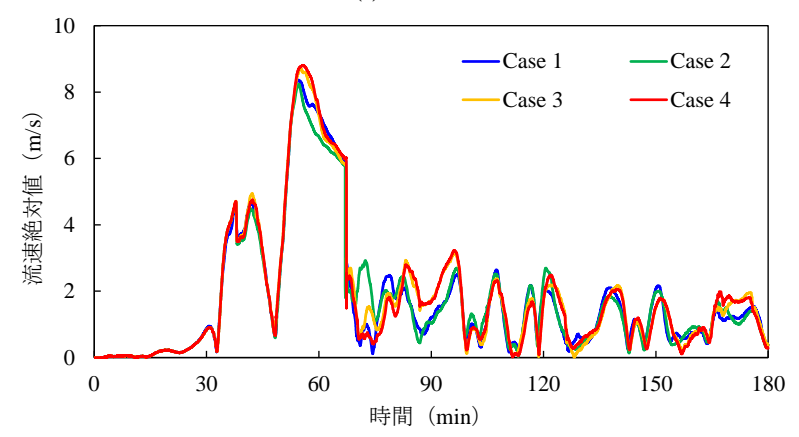

(b) 流速

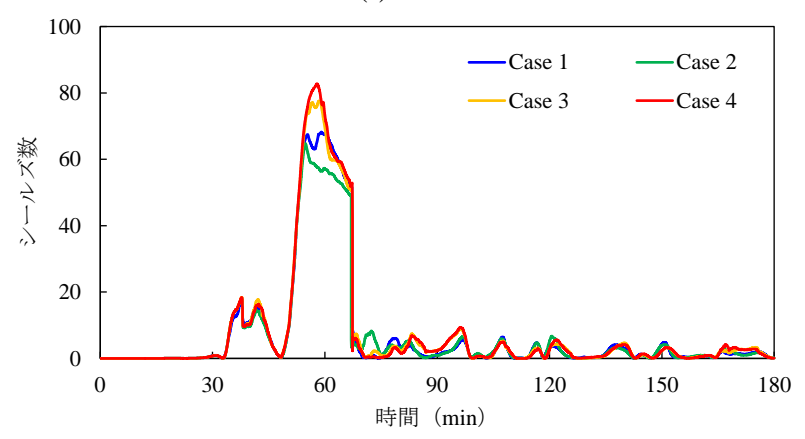

(c) シールズ数

図-5 静水深10mの位置における津波挙動

ク（約13m）に到達している．その後の引き波による約 65分後の最低水位は-8mを下回っており，初期水深 $10 \mathrm{~m}$ のこの地点における水深が非常に小さくなる.

流速絶対值の時系列（図-5(b)）からは，1波目の水位 上昇および下降の両方の過程で速い流れが生じているこ とが分かる．ただし，押し波時に比べると，引き波時の 流速の方が大きい. これは, 海底勾配の影響を受けて引 き波時に加速されることが原因といえる.

上述の水深と流速を用いて算定されるシールズ数

（図-5(c)）にも，1波目の押し波時と引き波時にピーク が認められる．ただし，押し波時の最大值が20程度であ るのに対して，引き波時には50以上にまで達しているこ とから，対象海岸では1波目の引き波時に非常に大きな 外力が作用したことが分かる．2波目以降は大きなシー ルズ数は現れない.

\section{（2）流砂パラメータによる砂移動特性の差異}

図-6に，静水深10mの位置における飽和浮遊砂濃度と

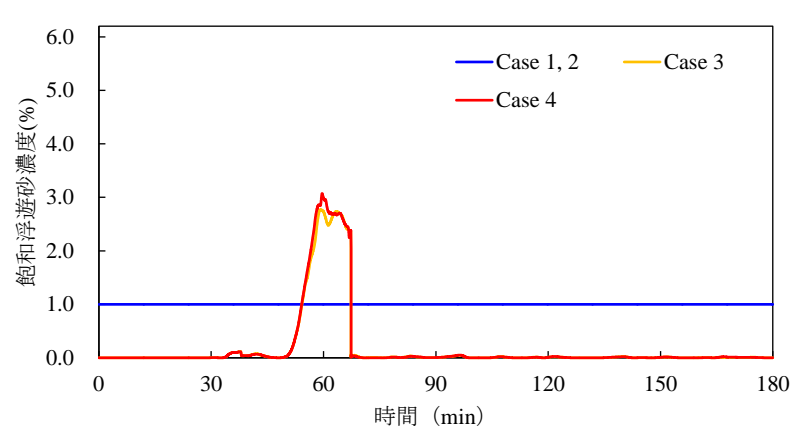

(a) 飽和浮遊砂濃度

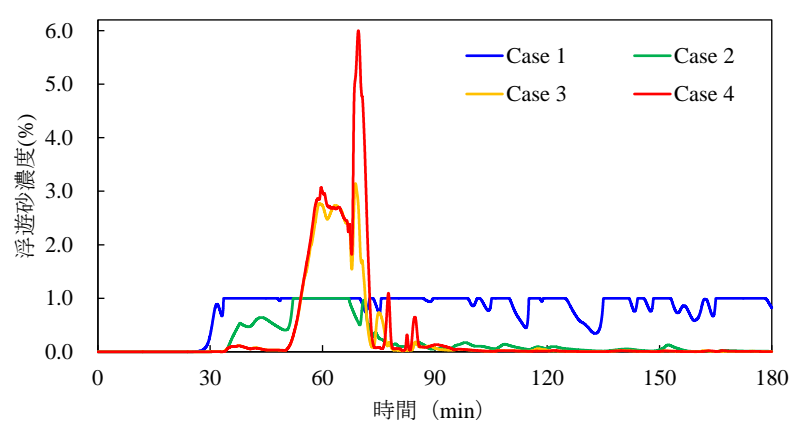

(b) 浮遊砂濃度

図-6 飽和浮遊砂濃度および浮遊砂濃度の時系列

浮遊砂濃度の時系列を示す。ここで，飽和浮遊砂濃度は Case 1，2では固定值（1\%）であり，Case 3，4では流況 に応じて式(1)で求められる值である，また，浮遊砂濃 度は津波移動床モデルの浮遊砂層内の土砂濃度を示す.

津波が到達した地震発生30分後以降のCase 1の浮遊砂 濃度は，ほぼ飽和浮遊砂濃度（1\%）で推移寸る。これ に対して, 流砂量係数が小さいCase 2 の浮遊砂濃度は,

Case 1より小さい．しかしながら，1波目の引き波時には， Case 2の浮遊砂濃度も1\%に達していることから，この時 間は大量の砂が巻き上げられる水理条件であるものの, 両ケースとも飽和浮遊砂濃度の制約により浮遊砂濃度が 1\%に抑えられていることが分かる.

Case 3，4の飽和浮遊砂濃度が大きくなるのは1波目の 引き波時のみであり，その最大值はCase 1，2で固定条件 とした $1 \%$ をきく上回る．それ以外の時間は，1波目の 押し波時を含めて飽和浮遊砂濃度が小さい. Case 3，4の 浮遊砂濃度は, ほぼすべての時間で流砂量係数による差 異が小さく, 飽和浮遊砂濃度とほぼ等しい. これらのこ とから，Case 3，4では，1波目の引き波時には大量の土 砂移動が計算される一方で, 他の時間の巻き上げ砂量は 飽和浮遊砂濃度の制約によって抑えられているといえる。 なお，図-6(a)，(b)を比較すると，Case3，4で浮遊砂濃度 が飽和浮遊砂濃度の值を上回る時間がある。これは，移 流や流況の急変による過飽和を許容しているためである.

図-7に，1波目の押し波時（40分後）および引き波時 (60分後) の浮遊砂濃度の空間分布を示寸. Case 1では, ほぼ全域で飽和浮遊砂濃度（1\%）となっている. Case2 


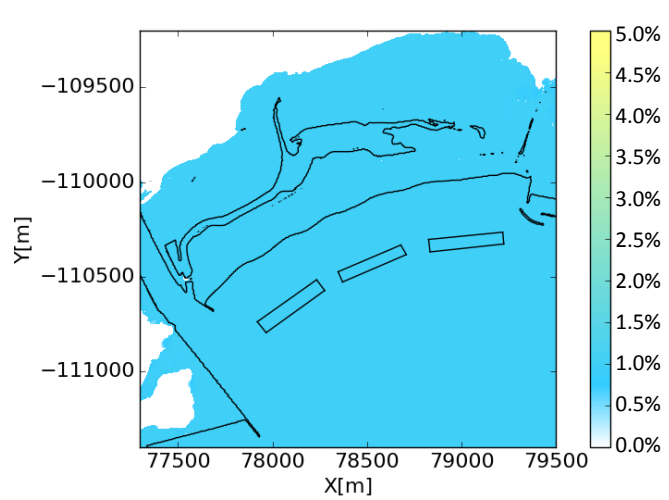

(a)Case1_地震発生40分後

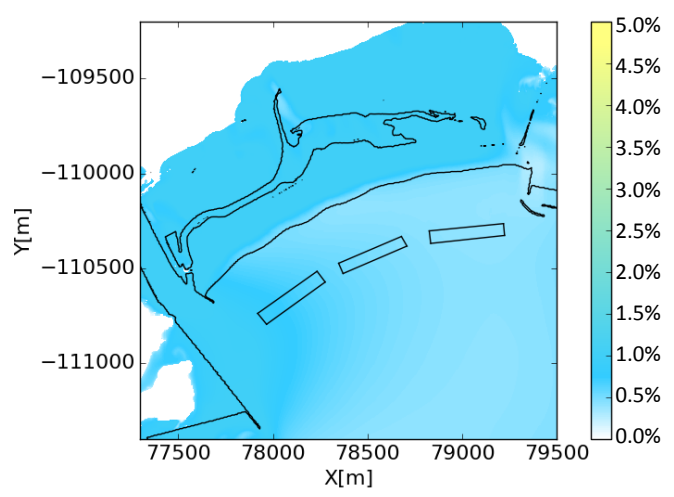

(c)Case2_地震発生40分後

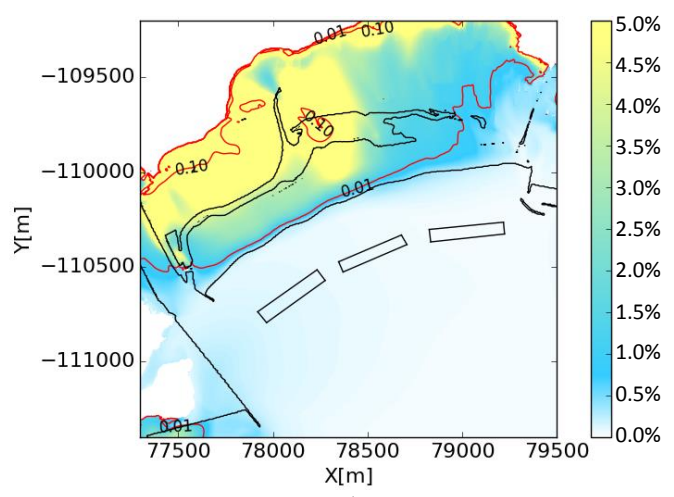

(e)Case3_地震発生40分後

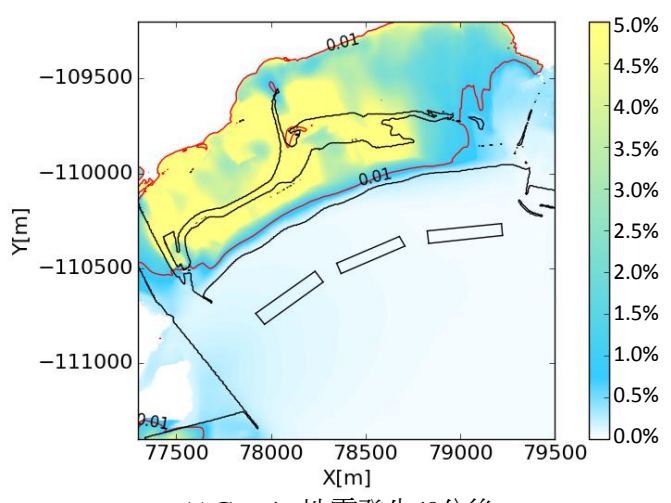

(g)Case4_地震発生40分後

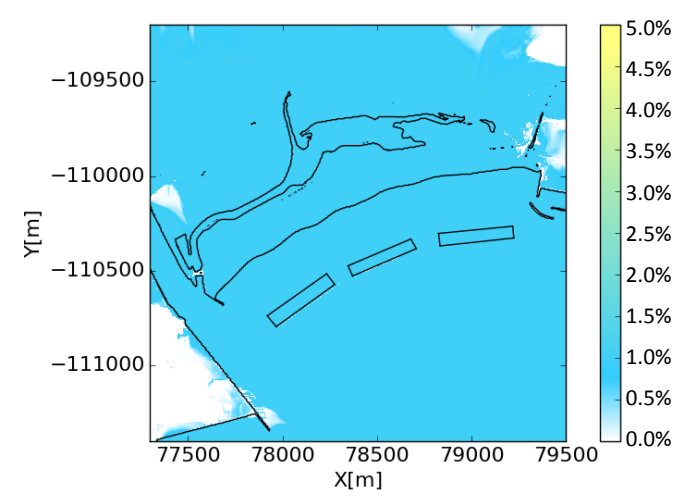

(b)Case1_地震発生60分後

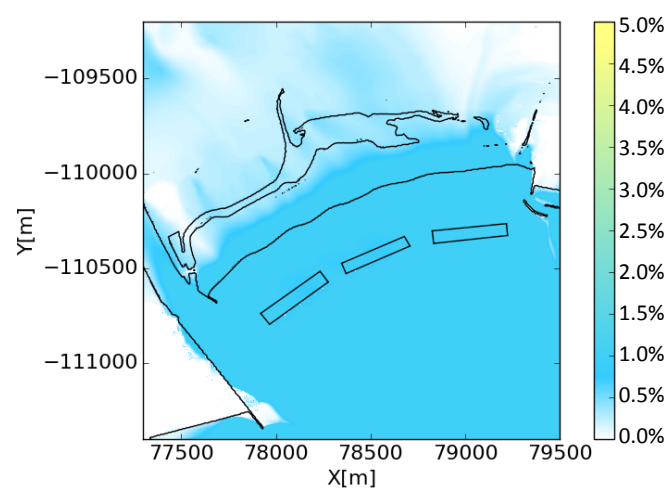

(d)Case2_地震発生60分後

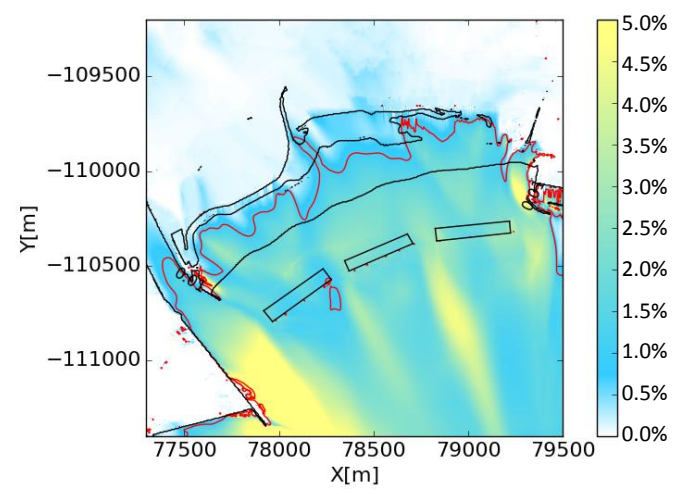

(f)Case3_地震発生60分後

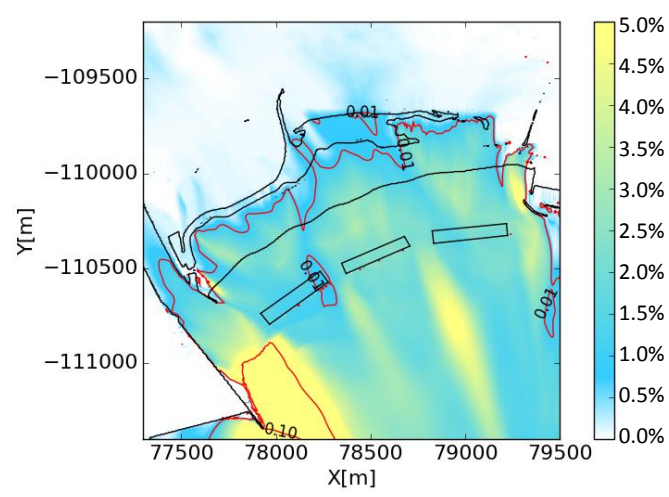

(h)Case4_地震発生60分後

図-7 浮遊砂濃度の空間分布（40分後 : 押し波時・60分後 : 引き波時，赤線は浮遊砂濃度 $1 \%$ 等值線 $)$

は，浮遊砂濃度が若干小さい領域があるものの，押し波 時には岸側，引き波時には沖側の広範囲で飽和浮遊砂濃 度（1\%）となっている。一方で，Case 3，4は浮遊砂濃 度の時空間的な変動が大きく, 押し波時には岸側で, 引 き波時では沖側で部分的に非常に大きな值が認められる.
これらの結果から，Case 1，2では1\%を超える浮遊砂 濃度が許容されないために侵食量が過小評価となったの に対して, Case 3，4では1波目の引き波時に生じる大量 の巻き上げが考慮できるために地形変化の良好な再現性 が得られたといえる。 また，図-7(f)，(h)にみられる引き 
波時の局所的な高濃度の浮遊砂の移動により， Case 3,4 では人工リーフ間の侵食が再現できたと考えられる.

\section{5. まとめ}

飽和浮遊砂濃度の設定によって砂移動特性が大きく異

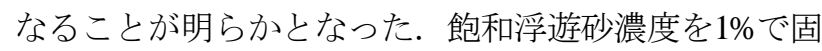
定した場合には，十分な巻き上げ砂量が許容されないた めに，侵食量が過小評価となった。一方，飽和浮遊砂濃 度を可変とした場合には，水理条件による時空間的な砂 移動量の差異を考慮することができ，大規模な地形変化 に対する良好な再現性を得ることができた。この際，飽 和浮遊砂濃度による制約の効果が大きいため, 流砂量係 数による計算結果の差異が小さいことが明らかとなった.

謝辞：本研究の実施にあたり，現地資料に関して国土交 通省国土技術政策総合研究所海岸研究室の加藤史訓室長 のご協力を得るとともに，国土交通省東北地方整備局岩 手河川国道事務所より貴重な現地資料の提供を受けた. また，関西大学の高橋智幸教授より貴重なご助言を頂い た.ここに記して深甚なる謝意を表する.

\section{参考文献}

1）高橋智幸, 首藤伸夫, 今村文彦, 浅井大輔 : 掃流砂 層・浮遊砂層の交換砂量を考慮した津波移動床モデ ルの開発, 海岸工学論文集, 第 46 巻, pp.606-610, 1999.

2)玉田崇, 田村保, 高橋智幸, 佐々木元 : 河川での津 波防災検討における津波移動床モデルの適用性に関 する研究, 土木学会論文集 B2(海岸工学), Vol.65, No.1, pp.301-305, 2009.

3) 高橋智幸, 黒川貴博, 藤田将孝, 島田広昭: 津波に よる土砂移動の粒径依存性に関する水理実験, 土木 学会論文集 B2(海岸工学), Vol.67, pp.231-235, 2011.

4) 森下祐, 高橋智幸 : 2011 年東北地方太平洋沖地震津 波来襲時の気仙沼湾を対象とした津波移動床モデル
の再現性向上，土木学会論文集 B2(海岸工学), Vol.70, No.2,pp.I_491-I_495, 2014.

5) 浅井大輔, 今村文彦, 高橋智幸, 首藤伸夫 : 地震津 波による大量土砂移動の可能性一安政東海地震津波 における伊豆半島入間での場合一, 津波工学研究報 告, Vol.16, pp.119-130, 1999.

6) 藤田尚毅, 稲垣和男, 藤井直樹, 高尾誠, 金戸俊 道：津波による海底地形変化評価モデルの現地適用 性に関する研究, 海洋開発論文集, 第 26 巻, pp.213218, 2010 .

7) 菅原大助, 成瀬元, 後藤和久 : 堆積粒子の巻き上げ に伴うエネルギー散逸を考慮した津波土砂移動の計 算と検証,日本堆積学会講演要旨, O27, 2014.

8) 今井健太郎, 菅原大助, 高橋智幸, 岩間俊二, 田中 仁 : 2011 年東北津波における北上川河口部の大規模 洗掘・堆積に関する数值的検討, 土木学会論文集 B2(海岸工学), Vol.71, No.2, pp.I_247-I_252, 2015.

9) 山下啓, 菅原大助, 高橋智幸, 今村文彦, 齋藤友一, 今任嘉幸, 甲斐恭, 上原均, 加藤季広, 中田一人, 坂良太郎, 西川朝雄: 岩手県陸前高田市における 2011 年東北地方太平洋域地震津波による大規模土砂 移動の再現計算, 土木学会論文集 B2(海岸工学), Vol.71, No.2, pp.I_499-I_504, 2015.

10) 加藤史訓, 野口賢二, 諏訪義雄, 坂上敏彦, 佐藤祥 昭：津波による地形変化に関する現地調査, 土木学 会論文集 B3(海洋開発), Vol.68, No.2, pp.I_174-I_179, 2012.

11) Satake, K., Y. Fujii, T. Harada and Y. Namegaya : Time and space distribution of coseismic slip of the 2011 Toho$\mathrm{ku}$ earthquake as inferred from tsunami waveform data, Bull. Seismol. Soc. Am., Vol.103, No.2B, pp.1473-1492, 2013.

12) Naruse, H., K. Arai, D. Matsumoto, H. Takahashi, S. Yamashita, G. Tanaka and M. Murayama: Sedimentary features observed in the tsunami deposits at Rikuzentakata City, Sedimentary geology, Vol.282, pp.199-215, 2012.

13）小谷美佐, 今村文彦, 首藤伸夫 : GIS を利用した津波 遡上計算と被害推定法, 海岸工学論文集, 第 45 巻, pp.356-360, 1998.

(2017.3.15 受付)

\title{
INFLUENCE OF COMPUTATIONAL PARAMETERS ON ACCURACY OF MOVABLE BED MODEL FOR TSUNAMIS
}

\author{
Tsuyoshi ARIMITSU, Shuugo MATSUDA, Yoshikane MURAKAMI, Takemi \\ SHIKATA, Koji KAWASAKI, Toyoaki MISHIMA, Ryotaro SHIMIZU and \\ Daisuke SUGAWARA
}

\begin{abstract}
Numerical simulations of sediment transport, which was caused by the 2011 Tohoku Tsunami, were conducted in order to investigate the influence of computational parameters on accuracy of movable bed model for tsunamis. Simulation results revealed that the amount of sediment transport differed depending on saturation concentration of suspended sediment. Erosion volume was underestimated in the case that saturation concentration was given as a constant value $(1 \%)$. On the other hand, erosion caused by the strong return flow was reproduced using saturation concentration of suspended sediment which varies depending on the flow fields. The simulation results also showed that the sediment transport coefficients in the governing equations had relatively less effect on the sediment transport.
\end{abstract}

